\title{
MICRO-HPLC SEPARATION OF SOME THENOYLTRIFLUOROACETONATES
}

Florentin TACHE, Andrei MEDVEDOVICI and George-Emil BAIULESCU

Department of Analytical Chemistry, Faculty of Chemistry, University of Bucharest, Blvd. Republicii no. 13, 70 346, Bucharest, Romania.

\begin{abstract}
Micro-HPLC separation and UV detection of some metal thenoyltrifluoroacetonates has been achieved. Cyano, octadecyl and HTTA modified silica gels were used as stationary phases. Data about separation and detection parameters optimization are also described.
\end{abstract}

\section{RESUMO}

\begin{abstract}
Alguns tenoiltrifluoroacetonatos metálicos foram separados por microcromatografia líquida de alta pressão e detectados com métodos ultravioletas. As fases estacionárias usadas forma silica gels modificados com ciano, octadecil e HTTA. A otimização dos parâmetros de separação e detecção foi descrita em termos dos dados experimentais.
\end{abstract}

\section{Keywords:}

micro-HPLC separation; UV detection; thenoyltrifluoroacetonates (Cr (III), $\mathrm{Al}(\mathrm{III}), \mathrm{Fe}$ (III), $\mathrm{Cu}$ (II), $\mathrm{Pb}$ (II), $\mathrm{Mn}$ (II), $\mathrm{Zn}$ (II), $\mathrm{Cd}$ (II), Co (II), Ni (II), Mg (II), Ca (II), Ba (II), Na (I), K (I)); process parameter optimization; HTTA bonded stationary phases. 
SOUTH. BRAZ. J. CHEM., Vol. 2, No.2, 1994

22

Micro-HIPLC Separation of Thenoyltrifluoroacetonates

\section{INTRODUCTION}

Separations of metal complexes using liquid chromatography are often preferred, compared to gas chromatographic techniques, due to the restriction withdrawing adopt volatility and thermal stability of analytes[1-3].

The advantage related to the higher selectivity of liquid chromatography is compensated, however, by lower efficiencies. The use of packed micro columns in HPLC is related to continuous effort in increasing the separation efficiency.

Liquid chromatography offers a variety of ways to differentiate partition of metal complexes between phases (adsorption [4-7], polarity [8-11], ionic association [12-14], ion exchange[15,16], ligand exchange [2], size exclusion[17-20]).

Particularities of the organic ligand ( thenoyltrifluoroacetone -HTTA) allows the use of different kinds of stationary phases and mobile phase mixtures, respectively, according to normal- or reversed-phase elution mode.

\section{EXPERIMENTAL PROCRDURE}

Separations were performed on a Hewlett Packard HPLC 1090 liquid chromatograph, modified for micro column use, fitted with an internal loop injection valve $(40 \mathrm{~nL})$. The mobile phase flow was splitted before the injection valve by a $\mathrm{T}$ connection throughout a $360 \mathrm{~mm} \times 4.6 \mathrm{~mm}$ i.d. column filled with RP8, $5 \mu \mathrm{m}$ stationary phase (as flow rate regulator for the analytical micro column). A pneumatic pump Haskel, model DST-15, was used for the slurry packing of the column.

The UV detection was done with an Kontron Instruments 433 capillary UV-Vis detection system (with variable wavelength) equipped with a $\mathrm{Z}$ shaped quartz flow-cell (dead volume of $90 \mathrm{~nL}$ and $2 \mathrm{~cm}$ pathway). Working wavelength was $355 \mathrm{~nm}$ and $222 \mathrm{~nm}$, respectively.

Response time was $0.5 \mathrm{sec}$.

The micro columns were $500 \mathrm{~mm} \times 0.32 \mathrm{~mm}$ i.d. fused silica capillaries, home 
packed with:

A. N-5-100 $\mathrm{C}_{1} / \mathrm{CN}, 5 \mu \mathrm{m}$ particle size, cyano modified silica gel stationary phase;

B. Nucleosil N-7-100 $\mathrm{C}_{18}, 7 \mu \mathrm{m}$ particle size, octadecyl modified silica gel stationary phase;

C. HTTA chemically modified BioSil 90D 5S silica gel, $5 \mu \mathrm{m}$ particle size, home synthesized (see Figure 1).

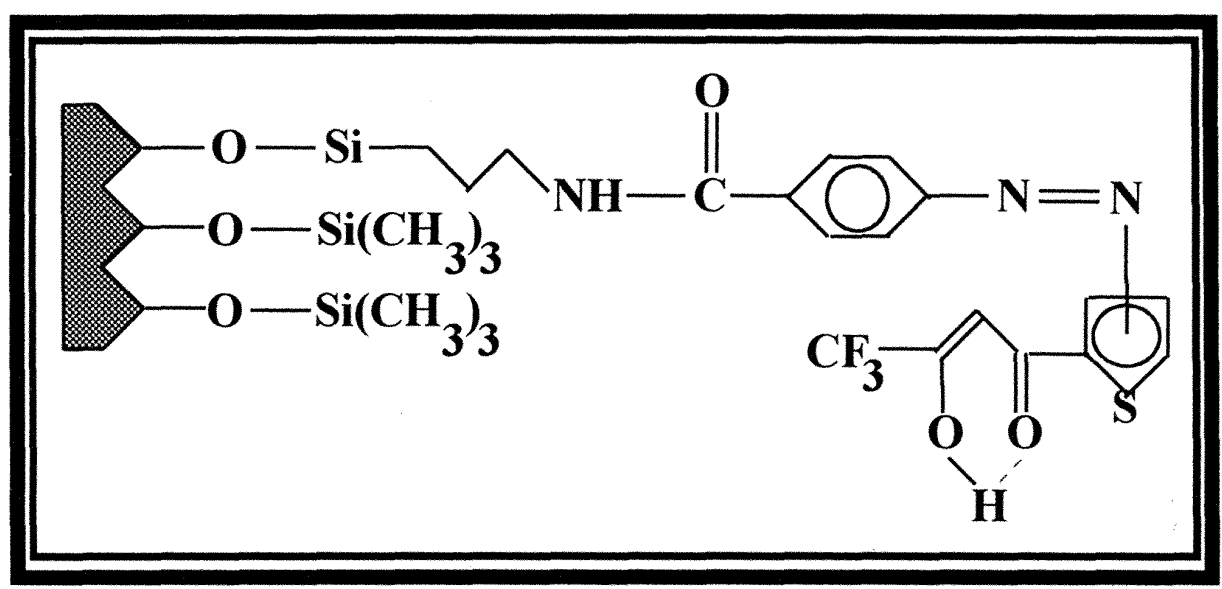

Figure 1. THE STRUCTURE OF THE HTTA CHEMICALLY MODIFIED BioSil 90 D 5S.

The packing of the stationary phases was performed by slurry packing method: $100 \mathrm{mg}$ stationary phase was dispersed in a mixture of carbon tetrachloride :methanol $(1: 1, \mathrm{v} / \mathrm{v})$. The packing was obtained at 500 bars during 4 hours, with acetonitrile as pumping solvent.

Flow rates through micro columns were selected in the range of $2-3 \mu \mathrm{L} / \mathrm{min}$. Mobile phase compositions were:

I. for stationary phase $\mathrm{A}$, hexane:dichlormethane binary system, in variate proportions;

II. for stationary phase B, acetonitrile:water binary system, in variate proportions; 
III. for stationary phase C, HTTA $1 \%$ in acetone.

Samples are represented by chloroform solutions $(2 \mu \mathrm{g} / \mu \mathrm{L})$ of HTTA complexes with $\mathrm{Cr}(\mathrm{III}), \mathrm{Al}(\mathrm{III}), \mathrm{Fe}(\mathrm{III}), \mathrm{Cu}(\mathrm{II}), \mathrm{Mn}(\mathrm{II}), \mathrm{Pb}(\mathrm{II}), \mathrm{Zn}$ (II), $\mathrm{Cd}(\mathrm{II}), \mathrm{Co}(\mathrm{II}), \mathrm{Ni}(\mathrm{II})$, $\mathrm{Mg}(\mathrm{II}), \mathrm{Ca}(\mathrm{II}), \mathrm{Ba}(\mathrm{II}), \mathrm{Na}(\mathrm{I})$ and $\mathrm{K}(\mathrm{I})$.

\section{RESULTS AND DTSCUSSION}

Due to the fact that HTTA is an asymmetrically substituted organic ligand, for those complexes with trivalent metallic ions which are exhibiting an octahedral structure, the relative positions of the organic reagent substituents around the metallic ion leads to different forms, assimilated as geometrical isomers. It is expected, for selective chromatographic systems, to observe the splitting of the peaks for such kind of complexes .

The only possible separations of geometrical cis-trans isomers is effective for $\operatorname{Cr}(\mathrm{TTA})_{3}$.

Cis-trans isomers of $\operatorname{Cr}(\mathrm{TTA})_{3}$ are separated (also from the free ligand) in both systems $\mathrm{A} /(\mathrm{I})$ and $\mathrm{B} /(\mathrm{II})$, respectively.

In the first case, the resolution between the two isomers is increasing with the increasing of hexane percentage in the mobile phase (see Figure 2 ). Figure 3 shows the typical chromatogram obtained with such elution system.

In the second case, the resolution between isomers is decreasing with the increasing of water percentage in the mobile phase (see Figure 4 ). Figure 5 is showing the typical chromatogram obtained with B/(II) system.

The cis isomer is obtained in a lower yield from the synthesis step. Thermodynamically, the lower energy state for the molecule corresponds to the trans isomer (similar substituents of the ligand spatially distributed around the metallic ion, resulting in low repulsive effects). It is normal to be expected that the most stable state should be obtained with higher probability. 
SOIJTH. BRA7. .J. CHEM., Vol. 2, No.2, 1994

F. Tache, A. Medvedovici \& G.E. Bãiulescu

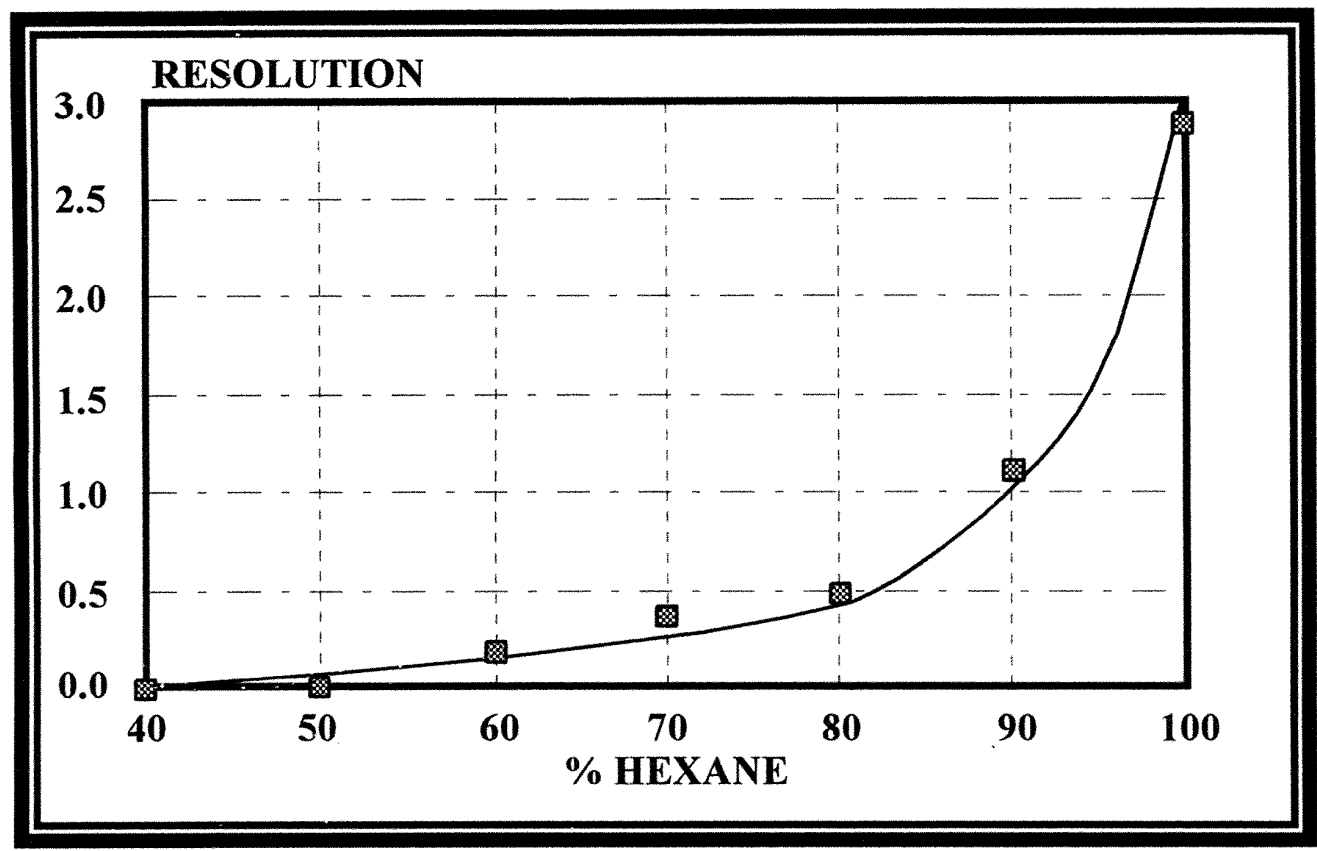

Figure 2. THE RESOLUTION VARIATION OF THE CIS-TRANS ISOMERS OF THE Cr(TTA) 3 AS A FUNCTION OF THE HEXANE PERCENTAGE IN THE MOBILE PHASE.

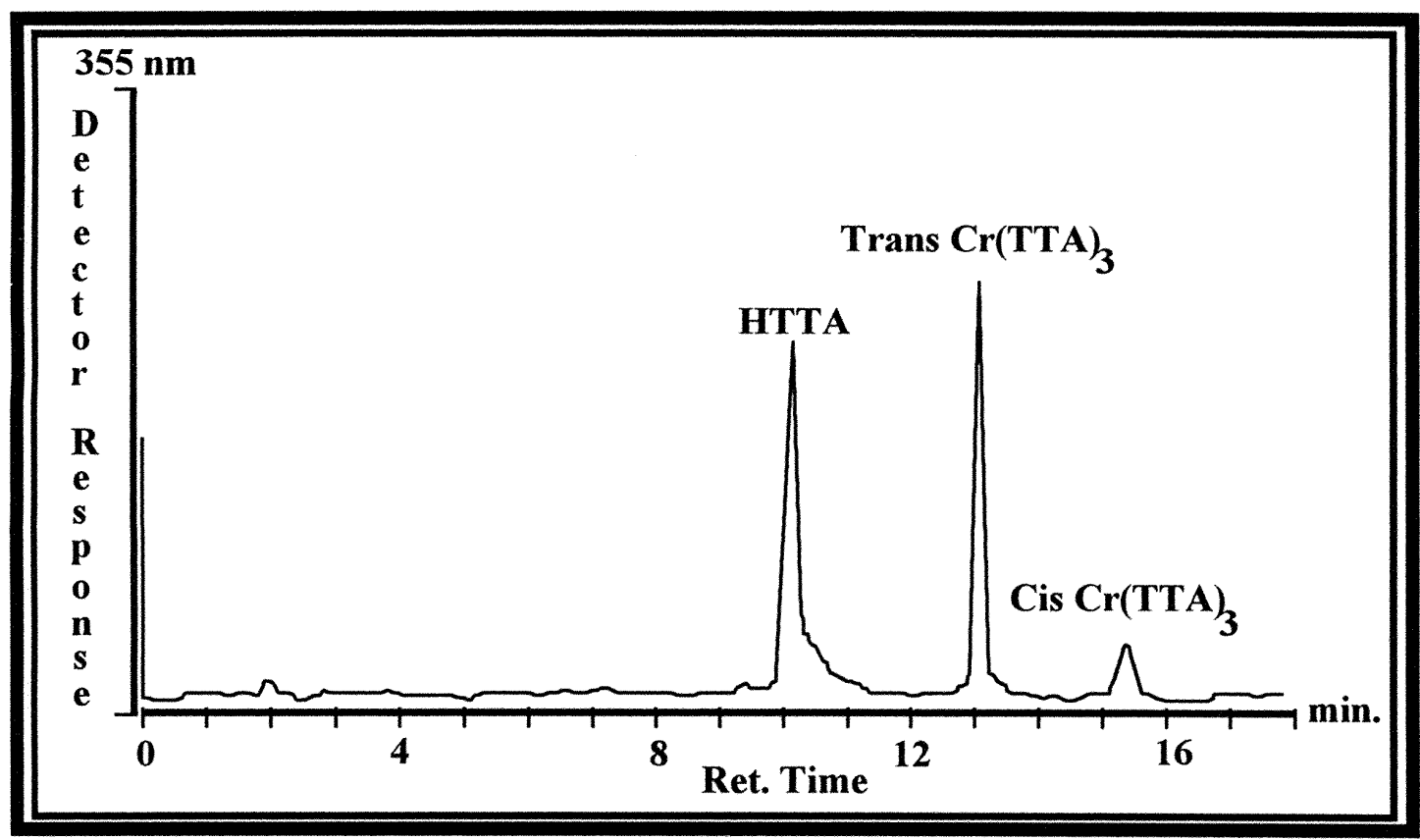

Figure 3. THE SEPARATION OF THE CIS-TRANS ISOMERS OF THE Cr(TTA) 3 ON A CYANO STATIONARY PHASE AND HEXANE AS MOBILE PHASE. 


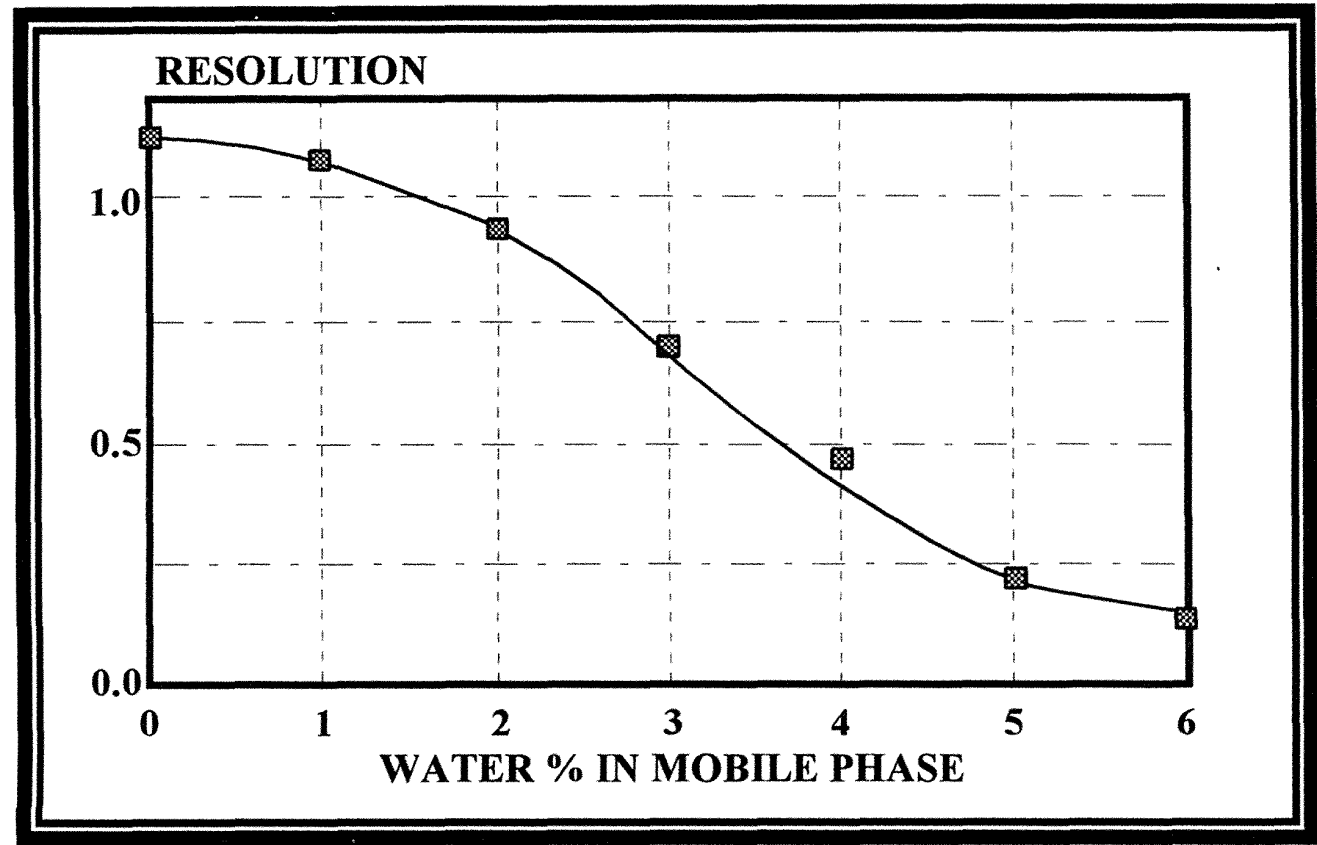

Figure 4. THE DEPENDENCE OF THE SEPARATION RESOLUTION OF THE CIS-TRANS ISOMERS OF THE Cr(TTA) 3 AS A FUNCTION OF THE WATER PERCENTAGE IN THE MOBILE PHASE.

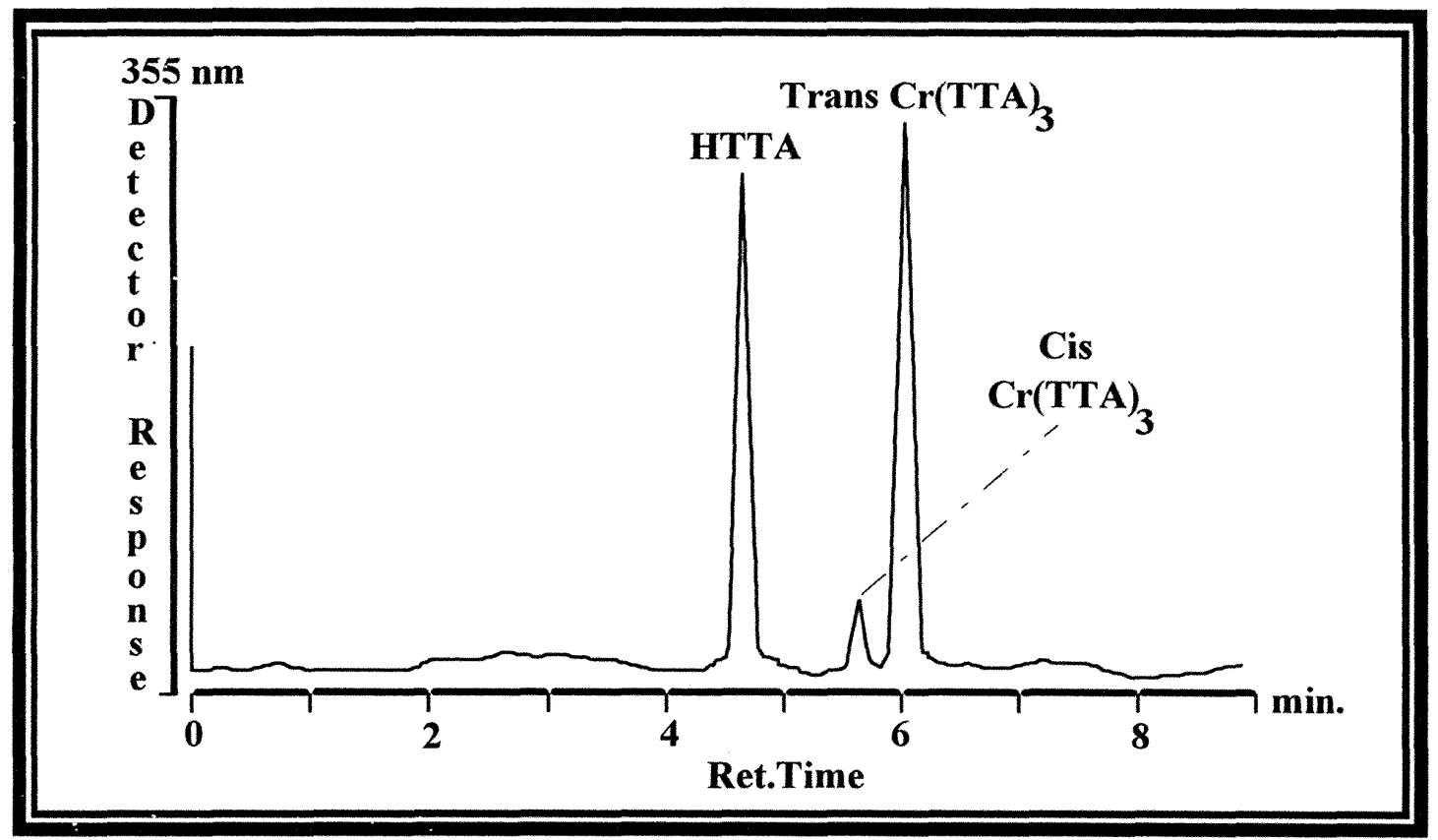

Figure 5. THE SEPARATION OF THE CIS-TRANS ISOMERS OF THE Cr(TTA) 3 ON THE OCTADECYL STATIONARY PHASE WITH ACETONITRILE/WATER MOBILE PHASE. 
The tighter arrangement of similar substituents of the organic ligand around the metallic ion (the case of cis isomer) is probably responsible for the molecule polarization. The higher polarity of the cis isomer is observable from the elution order (second eluted in $\mathrm{A} /(\mathrm{I})$ system and first eluted in $\mathrm{B} /(\mathrm{II})$ system, respectively).

For the $\mathrm{A} /(\mathrm{I})$ separation system, the mobile phase components are not important, it is not possible to obtain the separation of the HTTA complexes from the free ligand. Only the $\mathrm{Cr}$ (III) complex exhibits a different chromatographic behavior in comparison to all the other metallic chelates, being retained a longer period.

For the B/(II) separation system, notable results were obtained only for the mixtures $\mathrm{Cu}(\mathrm{TTA})_{2}+\mathrm{Pb}(\mathrm{TTA})_{2}+\mathrm{Cr}(\mathrm{TTA})_{3}$ and $\mathrm{Fe}(\mathrm{TTA})_{3}+\mathrm{Cr}(\mathrm{TTA})_{3}+$ $\mathrm{Al}(\mathrm{TTA})_{3}$, respectively. However, resolution between $\mathrm{Cu}$ (II) and $\mathrm{Pb}$ (II) HTTA complexes, $\mathrm{Al}(\mathrm{III})$ and $\mathrm{Cr}(\mathrm{III}) \mathrm{HTTA}$ complexes, respectively, did not show optimum values. Resolution remains lower, even for optimized programmed gradient elution.

For $\mathrm{C} /(\mathrm{III})$ separation system, differentiation between analytes is presented in Table 1, where the capacity factors characterizing elution of HTTA metal complexes are reviewed. Figure 6 shows some typical chromatograms obtained with this system.

When the mobile phase contains the free ligand, UV detection becomes generally inoperant and the post-column derivatization step is necessary. Due to the fact that HTTA complexes are exhibiting major hyperchromic displacements in UV spectral region, it is possible to observe the elution of analytes from the chromatographic column, even in the presence of the free ligand into the mobile phase. The derivatization step is no necessary anymore in such a case.

Figure 7 shows the resulting UV spectrum obtained from an acetone $4 \mathrm{mg} / \mathrm{L}$ $\mathrm{Al}(\mathrm{TTA})_{3}$ solution, compensated with $1 \%$ HTTA acetone solution. $222 \mathrm{~nm}$ and $379 \mathrm{~nm}$ signals could be used for monitoring metal complexes elution. Such a 


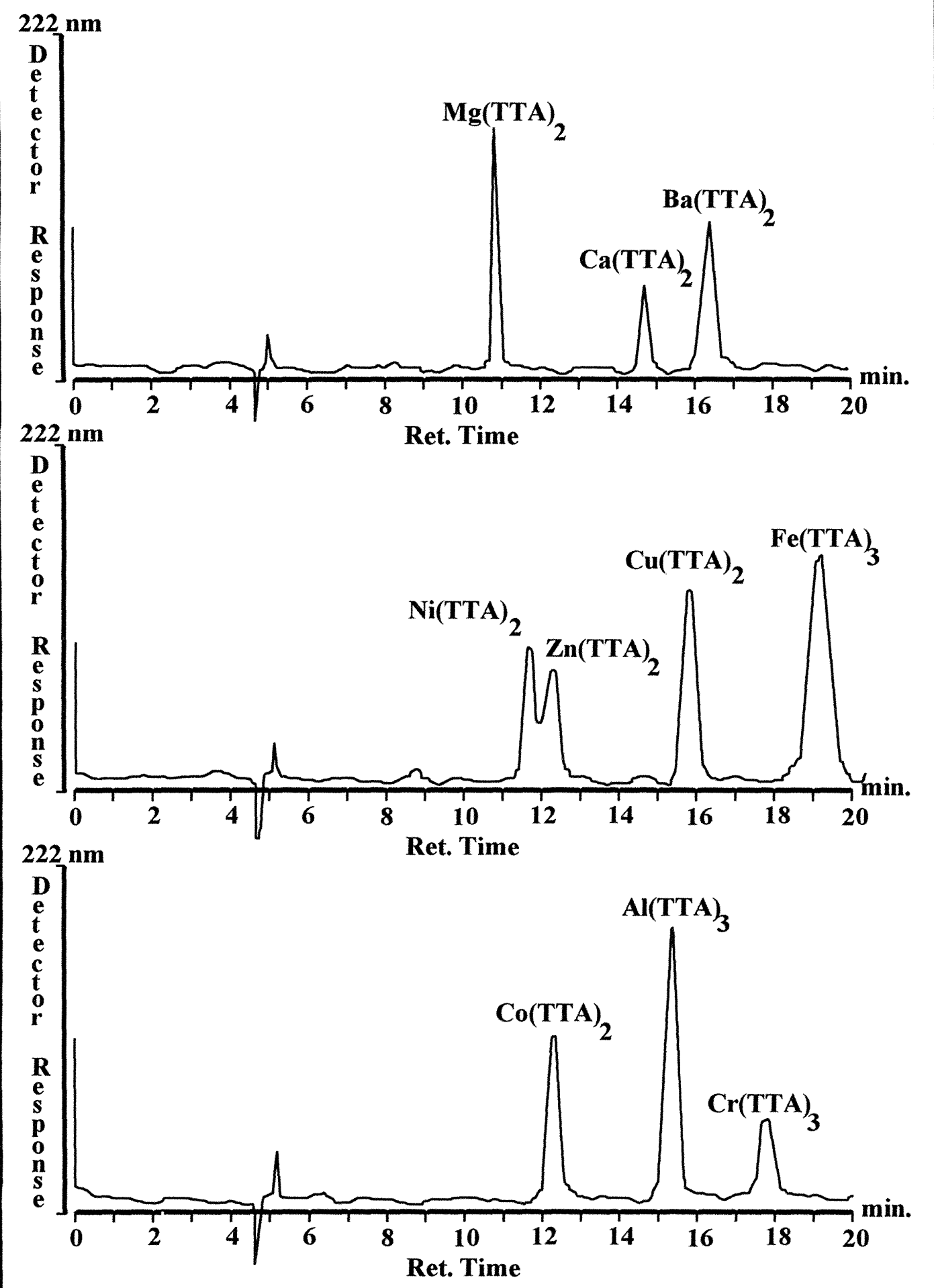

Figure 6 TYPICAL CHROMATOGRAMS OBTAINED IN C/III SEPARATION MODE FOR HTTA METALLIC COMPLEXES. 
SOUTH. BRAZ. J. CHEM., Vol. 2, No.2, 1994

F. Tache, A. Medvedovici \& G.E. Bãiulescu

Table 1. CAPACITY FACTORS (K) CHARACTERIZING ELUTION OF METALLIC COMPLEXES WITH HTTA, ACCORDING TO C/III SEPARATION SYSTEM.

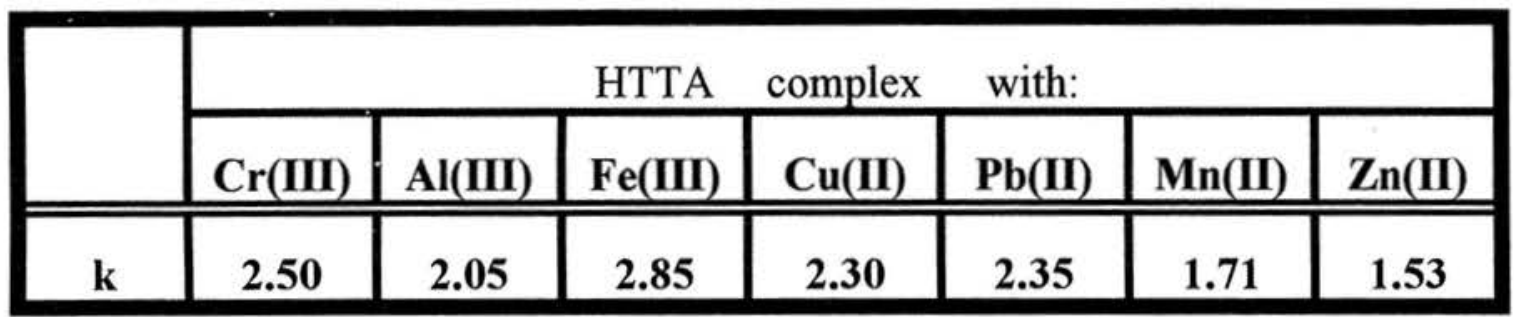

\begin{tabular}{|c|c|c|c|c|c|c|c|}
\hline \multicolumn{7}{|c|}{ HTTA } & \multicolumn{1}{l|}{ complex } \\
\hline $\mathrm{Cd}(\mathrm{II})$ & $\mathrm{Co}(\mathrm{II})$ & $\mathrm{Ni}(\mathrm{II})$ & $\mathrm{Mg}(\mathrm{II})$ & $\mathrm{Ca}(\mathrm{II})$ & $\mathrm{Ba}(\mathrm{II})$ & $\mathrm{Na}(\mathrm{I})$ & $\mathrm{K}(\mathrm{I})$ \\
\hline \hline 2.79 & 1.52 & 1.35 & 2.25 & 1.95 & 1.21 & 1.49 & 1.48 \\
\hline
\end{tabular}

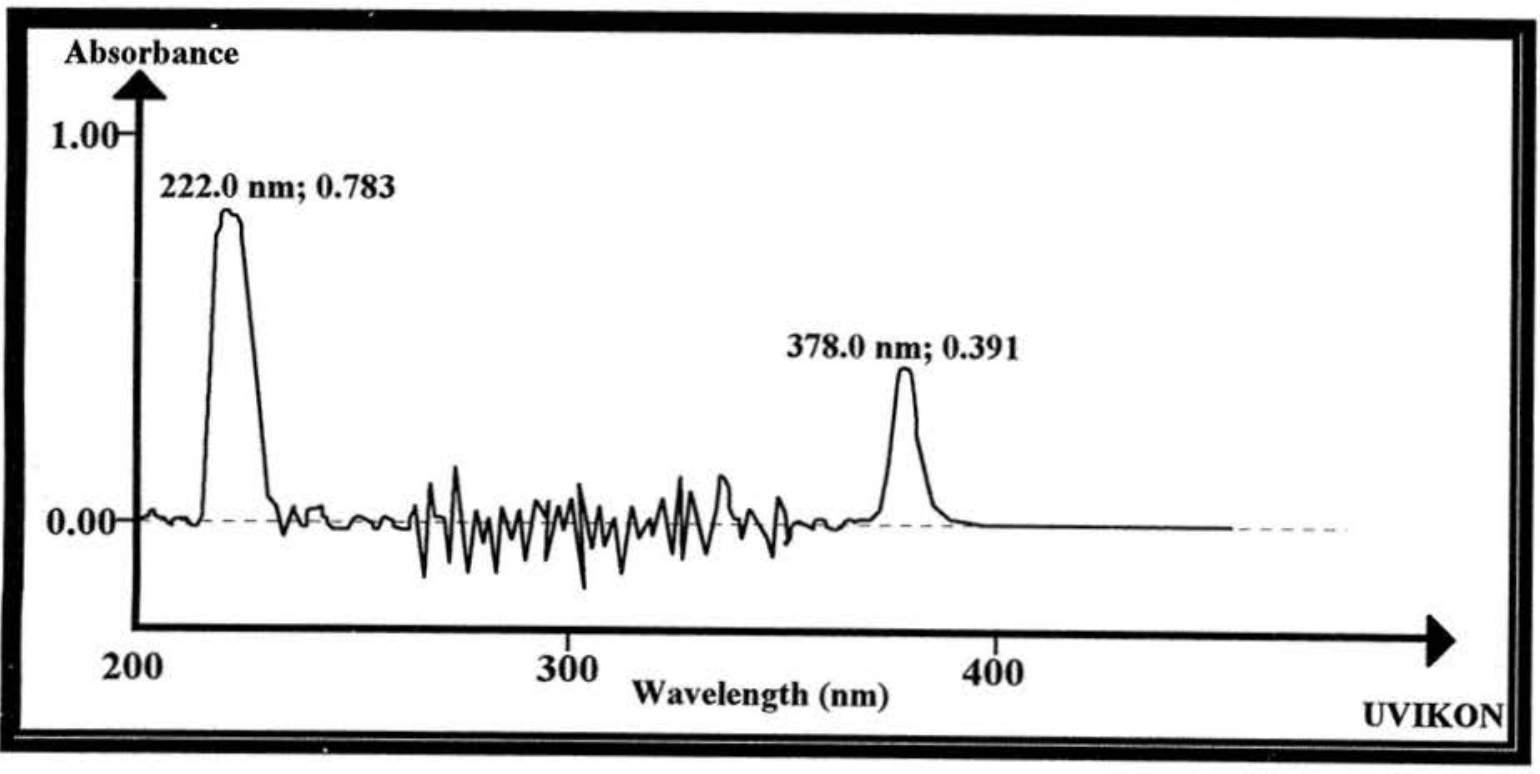

Figure 7 UV SPECTRUM OF AN ACETONE SOLUTION CONTAINING 4 mg/L Al(TTA) 3 COMPLEX, REGISTERED WITH $1 \%$ HTTA IN ACETONE AS REFERENCE. 
detection method is not related with a lack of sensitivity, when . compared to a classical post-column derivatization step followed by Vis detection. Detection limits are similar to those obtained after pyridyl-azoresorcinol (PAR) postcolumn derivatization reaction and Vis detection. $Z$ shaped flow cells are not recommended for use, due to the high energy looses during compensation for extremely long pathlengths.

\section{Conclusions}

It can be concluded that LC separation of thenoyltrifluoroacetonates is hard to be achieved when the mechanisms are based on the differentiation of the polarity of solutes. Probably, ligand molecules are "packed" around the metallic ion in a similar way, resulting in a low differentiation from the polarity point of view.

The $\beta$ - diketonic structure substituents (trifluoromethyl - polar, thyenyl - non polar) confer an intermediate polar character to metal complex molecule. When the basic mechanism of the chromatographic partition changes (ligand exchange mechanism), good results are obtained and $\mu$ - column techniques contribute to better efficiencies.

\section{REFERENCES}

1. K. Robards; P. Starr and E. Patsalides, Analyst, 116, 1247-1273 (1991).

2. B.R. Willeford and H. Veening, J.Chromatogr., 251, 61- 88 (1982).

3. C.A. Tollinche and T.H. Risby, J.Chromatogr.Sci., 16,448 - 454 (1978).

4. Yu. Nikitin, M.B. Morozowa, S.L. Lanin, T.A. Bol'shova, V.M. Ivanov and E.M. Basova, Talanta, 34, 223- 227 (1987).

5. Yu. A. Zolotov, O.M. Petrukhin, A.R. Timerbaev, M.V. Evstiferov, V.V. Salov and N.G. Vanifatova, Analyst, 114, 1137- 1143 (1989).

6. L. Liodakis, A. Pappa and G. Parissakis, J.Chromatogr.Sci., 27, 147 - 153 (1989). 
SOUTH. BRAZ. J. CHEM., Vol. 2, No.2, 1994

F. Tache, A. Medvedovici \& G.E. Bäiulescu

7. J. Hagan, S. Taylor, and M. Tweedlew, Anal.Chem. 60, 514- 520 (1988).

8. Y. Nagaosa, T. Suenaga and A. Bond, Anal.Chim.Acta, 235, $279-283$ (1990).

9. S. Ichinoki and M. Yamazaki, J.Chromatogr.Sci., 28 , 258 - 264 (1990).

10. J. Shofstahl and J. Hardy, J.Chromatogr.Sci., 28, 225 - 229 (1990).

11. K. Nakajima, T. Yasuda and H. Nakazawa, J.Chromatogr., 502, 379 - 383 (1990).

12. N. Hoshino, K. Nakano and T. Yotsuyanagi, Analyst, 115, 133 - 137 (1990).

13. P. Haddad and N. Rochester, Anal.Chem., 60, 536 - 541 (1988).

14. Y. Zhao and C. Fu, Anal.Chim.Acta, 230, 23 - 29 (1990).

15. G. Schwedt and P. Schneider, Fresenius Z.Anal.Chem., 325, 116 - 121 (1986).

16. D. Cox, G. Harrison, P. Jandik and W. Jones, Food Technology, 41, 245 -251 (1985), .

17. K. Saitoh, M. Satoh and N. Suzuki, J.Chromatogr., 92, 291 - 297 (1974).

18. K. Saitoh and N. Suzuki, J.Chromatogr., 109, 333 - 339 (1975).

19.N. Suzuki, K. Saitoh and M. Shibukawa, J.Chromatogr., 138, 79 - 87 (1977).

20. H. Noda, K. Saitoh and N. Suzuka, J.Chromatogr., 168, 250 - 254 (1979). 